\title{
Frequency of allelic variants of the TMPRSS2 gene in a prostate cancer-free Southwestern Colombian population
}

\section{Prevalencia de variantes alélicas del gen TMPRSS2 en una población del suroeste de Colombia libre de cáncer de próstata}

Herney Andrés García-Perdomo, ${ }^{1,2}$ Bryan David Zamora-Segura, ${ }^{2}$ Adalberto Sánchez ${ }^{1,3}$

\begin{abstract}
OBJECTIVE: To describe the frequency of the TMPRSS2 gene and its variants in a prostate cancer-free Southwestern Colombian population.

MATERIALS AND METHODS: An observational study was conducted that included cancerfree persons, regardless of age, from Southwestern Colombia. Blood samples were drawn from the patients for DNA extraction. Blood drops were collected and dried on filters and immersed in phosphate buffer, utilizing the DNeasy kit. The preparation process was carried out using the TruSeq Exome Library Prep ${ }^{\circledR}$ kit and the resulting libraries were normalized with the TruSeq Rapid Exome ${ }^{\circledR}$ kit. The commercial kits were provided by Illumina ${ }^{\circledR}$. We sequenced the full exome and identified the variants associated with the TMPRSS2 gene. Descriptive statistics were employed for the data analysis.

RESULTS: The study population was made up of 162 persons from whom 7,315,466 sequence data were obtained. The TMPRSS2 gene was found in 414 data $(4.3 \%)$. The most common SNP was rs140530035 (32.1\%) and the most relevant SNP sequenced was rs12329760 (10.6\%).

CONCLUSION: TMPRSS2 was not frequent in the population studied. The most important polymorphism associated with the TMPRSS2 gene was rs12329760.

KEYWORDS: Gene; Prostate cancer; TMPRSS2; Polymorphism.

Resumen

OBJETIVO: Estimar la prevalencia del gen TMPRSS2, y sus variantes, en pacientes libres de cáncer de próstata de una población del suroeste de Colombia.

MATERIALES Y MÉTODOS: Estudio observacional, al que se incluyeron pacientes libres de cáncer de próstata, sin importar su edad, residentes de una población del sudoeste de Colombia. Se recolectaron muestras de sangre para extraer el ADN mediante filtros, inmersos en una solución tampón de fosfato, para evaluarse en el equipo comercial DNeasy. Para la lectura de resultados se utilizó el manual TruSeq Exome Library Prep ${ }^{\circledR}$ y se normalizaron con TruSeq Rapid Exome ${ }^{\circledast}$, proporcionados por Illumina ${ }^{\circledast}$. Se obtuvo la secuenciación del exoma completo y se identificaron las variantes asociadas con el gen TMPRSS2. Para el análisis de los datos se implementó estadística descriptiva.

RESULTADOS: Se registraron 162 pacientes, de quienes se obtuvieron 7,315,466 datos de secuenciación. El gen TMPRSS2 se encontró en 414 datos (4.3\%). El SNP más común fue rs140530035 (32.1\%) y el secuenciador más relevante rs12329760 (10.6\%). CONCLUSIÓN: la identificación del gen TMPRSS2 no es frecuente en pacientes libres de cáncer de próstata del suroeste de Colombia. El polimorfismo rs12329760 tuvo mayor relación con el gen TMPRSS2.
\end{abstract}

PALABRAS CLAVE: Gen TMPRSS2; cáncer de próstata; polimorfismo.

\author{
MD, MSc, EdD, PhD, FACS, Associate \\ Professor Universidad del Valle. \\ ${ }^{2}$ MD, UROGIV Research Group - Uni- \\ versidad del Valle. \\ ${ }^{3}$ BSC PhD, LABIOMOL Research Group \\ Universidad del Valle.
}

Recibido: agosto 2018

Aceptado: septiembre 2018

\section{Correspondencia}

Herney Andrés García Perdomo Herney.garcia@correounivalle.edu.co Twitter: @herneygarcia

Este artículo debe citarse como García-Perdomo HA, Zamora-Segura $B D$, Sánchez A. Frequency of allelic variants of the TMPRSS2 gene in a prostate cancer-free Southwestern Colombian population. Rev Mex Urol. 2018 sept-oct;78(5):354-358. DOI: https://doi.org/10.24245/revmexurol.v78i5.2454 


\section{INTRODUCTION}

One of the most prevalent neoplastic pathologies associated with male sex is prostate cancer. The estimated prevalence is 1.1 million people worldwide ${ }^{1-3}$ and it is impacted by ethnicity and geographic location. ${ }^{4}$ Populations of African descent are the most affected, showing an $11 \%$ increase in prevalence in recent years. ${ }^{5}$ The Southwest region of Colombia is inhabited by populations of Latin American and African descent in approximately the same proportion but with different rates of disease incidence. ${ }^{6}$

Variants of certain genes have been associated with a higher frequency of prostate cancer (BRCA1-2, ATM, NBN, TMPRSS2, among others). ${ }^{7}$ Serine proteases, such as the TMPRSS2 gene, are recognized through their mechanisms of action in inflammatory and immune processes. That gene is located on chromosome 21 q22.3 and is expressed at the apex of the secretory epithelium of the glands. Fusion with members of the ETS family is the most frequent chromosomal re-arrangement found in $50 \%$ of prostate cancers, mainly produced by the microdeletion of a portion of the TMPRSS2 gene. ${ }^{8}$ The TMPRSS2 gene and the fusion gene (TMPRSS2:ERG) have been associated with the severity and prognosis of prostate cancer, although the actual pathophysiologic process or the variant associated with that condition are not very well known. ${ }^{9}$ The fusion gene has been widely studied and at present has been postulated as one of the most important biomarkers for diagnostic and prognostic purposes in the prostate cancer population. ${ }^{10}$ There are reports in the literature on the single nucleotide polymorphisms (SNPs) most frequently related to those clinical scenarios.

The present study is important because there are no similar descriptive studies characterizing the presence of the TMPRSS2 gene and its variants in a population from Southwestern Colombia.
Our study focuses on describing the frequency of the allelic variants of the TMPRSS2 gene in that population.

\section{MATERIALS AND METHODS}

A descriptive, observational study was conducted on persons, regardless of age, from Southwestern Colombia (Nariño, Cauca, Putumayo, and Valle), within the time frame of 2014 to 2016.

\section{Sample size}

According to the expected frequency for hereditary prostate cancer $(\approx 15 \%)$, alpha $5 \%$, and an expected error of $5 \%$, the calculated sample size was 162 people and convenience sampling was carried out.

Complete exome sequencing was performed, which enabled the sequencing of all proteincoding regions (exome) in the genome, thus identifying the variants that could alter the sequence of a protein. It was carried out as follows:

\section{DNA extraction}

Blood was drawn from each patient for DNA extraction. All drops of blood were collected and dried on filter paper. The filter paper was then immersed in a phosphate buffer utilizing the DNeasy kit from the QIAGEN ${ }^{\circledR}$ company (Hilden, Germany-Operational). Each extraction was quantified, and its quality was verified, to continue the sequencing processing.

\section{Sequencing protocol}

DNA aliquots from each sample underwent a preparation process with the TruSeq Exome Library Prep ${ }^{\circledR}$. The resulting libraries were then normalized for sequencing using the TruSeq Rapid Exome ${ }^{\circledR}$. The kits were provided by Illumina ${ }^{\circledR}$ from San Diego, California, USA. The normalized 
fragments with their corresponding adaptors for sequencing were charged in a HiSeq2500 machine.

We sequenced the full exome and identified the related variants, specifically the SNPs for the TMPRSS2 gene that is associated with prostate cancer (PCa).

The present project was conducted following all ethical international standards. Descriptive statistics were performed in $\mathrm{R}$ and the results are shown in frequency tables for each gene and its associated variants. Finally, we looked for the variants in the following public databases: Exome Aggregation Consortium (ExAC), PharmGKB, ${ }^{11}$ Clinvar, ${ }^{12}$ Ensemble, and dbSNP, ${ }^{13}$ searching for a pattern through which we could use the variants we found as markers.

\section{RESULTS}

One hundred sixty-two patients were included in the study, providing 7,315,466 sequence data, and the TMPRSS2 gene was found in 414 data $(4.3 \%)$. Missense variants were identified in $23 \%$ of the data, although the most frequent variants were synonymous variants and introns. Only one stop variant was found in those data (Table 1).

In addition, the most common variants for the TMPRSS2 gene were: rs140530035 (32.12\%), rs17854725 (19.8\%), and rs2298659 (13.5\%) (Table 2).

Table 1. Associated variants

\begin{tabular}{|l|c|c|}
\hline Variant & $\begin{array}{c}\text { Absolute } \\
\text { Frequency }\end{array}$ & $\begin{array}{c}\text { Percentage } \\
(\%)\end{array}$ \\
\hline 5 UTR & 3 & 0.72 \\
\hline Intron & 144 & 34.78 \\
\hline Missense & 98 & 23.67 \\
\hline Stop & 1 & 0.24 \\
\hline Synonymous & 168 & 40.58
\end{tabular}

Table 2. Variants identified for TMPRSS2 gene

\begin{tabular}{|l|c|c|}
\hline Variants & Absolute Frequency & Percentage (\%) \\
\hline $\begin{array}{l}\text { No identifier } \\
\text { available }\end{array}$ & 36 & 8.70 \\
\hline rs12329760 & 44 & 10.63 \\
\hline rs140530035 & 133 & 32.13 \\
\hline rs143049780 & 1 & 0.24 \\
\hline rs148125094 & 1 & 0.24 \\
\hline rs149527323 & 1 & 0.24 \\
\hline rs17854725 & 82 & 19.81 \\
\hline rs181414852 & 1 & 0.24 \\
\hline rs2298659 & 56 & 13.53 \\
\hline rs3787950 & 15 & 3.62 \\
\hline rs61735789 & 2 & 0.48 \\
\hline rs61735790 & 1 & 0.24 \\
\hline rs61735792 & 1 & 0.24 \\
\hline rs61735793 & 1 & 0.24 \\
\hline rs61735794 & 3 & 0.72 \\
\hline rs61735795 & 1 & 0.24 \\
\hline rs75603675 & 35 & 8.45 \\
\hline
\end{tabular}

\section{DISCUSSION}

Transmembrane protease serine 2, also called TMPRSS2, is a protease composed of 492 amino acids expressed on the cell surface of multiple organs and they are theorized to be strategically located to regulate cell-cell interactions. The TMPRSS2 gene has been shown to be positively regulated by androgenic hormones in neoplastic tissue, possibly modulating the inflammatory response of prostate cells through the activation of PAR-2. ${ }^{14-15}$

Prostate cancer is one of the most frequent cancers in males and the TMPRSS2 gene has historically been associated with that malignant tumor. Numerous authors have conducted studies over the past decades in an attempt to link the presence of the TMPRSS2 gene with the frequency of cancer and its prognosis. ${ }^{16}$ Although 
there are studies that have found that the TMPRSS2 gene does not represent a worse prognosis for prostate cancer, ${ }^{17}$ an important fusion of that gene with the ERG gene was described, with an increasing relation to the diagnosis and aggressiveness of prostate cancer (present in $50 \%$ of high-risk prostate cancers)..$^{18-19}$

We found a low frequency of the allelic variant associated with the TMPRSS2:ERG fusion gene in our cancer-free population from Southwestern Colombia. The rs 12329760 variant, albeit not the most frequent SNP found in the present study, is reported in the literature to have a non-negligible allele frequency (AF) in populations from East Asia and Northern Europe (0.38 and 0.37, respectively), with a major homozygote ratio (> $7 \%)$. Frequency in the Hispanic population is 0.155 , with a low number of homozygotes (20). It should be noted that Southwestern Colombia has a large population of African descent, in which a higher frequency of said allelic variant (0.29) has been identified. That is an important fact to keep in mind when identifying new biomarkers for prostate cancer. ${ }^{20}$

The most sequenced polymorphism in the present study was rs140530035. It is a very common intron in the world population and the allele frequency of that variant reaches $0.9 .^{21}$ Comparing populations, inhabitants of northern Europe (Finland) have an AF of 0.99, whereas it is only 0.66 in the so-called Latino population, according to Lek et al. ${ }^{21}$

The rs 17854725 and rs2298659 polymorphisms are synonymous variants that are rare in the Latin American population, according to the literature, with an AF of 0.15 or less, and they have no known pathologic associations. Likewise, the rs75603675 polymorphism is not known to be associated with any pathology. ${ }^{21}$

\section{Strengths and limitations}

The present study is the first to describe the relation of the TMPRSS2 gene and its allelic variants to a Southwestern Colombian cancer-free population. An advantage of the project was the quality of the study's samples, analyses, and data. Several variants associated with the TMPRSS2 gene were identified. That is very important information for the performance of future longitudinal studies in cancer-free patients to determine the risk for that disease.

A limitation of the present study was the fact that we did not find any information associated with the presence of a pathologic relationship to prostate cancer.

\section{CONCLUSIONS}

The TMPRSS2 gene was not frequent in the cancer-free Southwestern Colombian population studied. Nonetheless, the most common variants for the TMPRSS2 gene were: rs140530035 $(32.12 \%)$, rs17854725 (19.8\%), and rs2298659 $(13.5 \%)$.

\section{REFERENCES}

1. Bray F, et al. Global estimates of cancer prevalence for 27 sites in the adult population in 2008 GLOBOCAN. Int J Cancer 2013;132(5):1133-45. DOI: 10.1002/ijc.27711

2. Valencia $\mathrm{O}$, et al. Incidence and Prevalence of Cancer in Colombia: The Methodology Used Matters. J Glob Oncol 2018;(4):1-7. DOI: 10.1200/JGO.17.00008

3. Bashir MN. Epidemiology of Prostate Cancer. Asian Pacific J Cancer Prev 2015;16(13):5137-41.

4. Rebbeck TR. Prostate cancer genetics: variation by race, ethnicity, and geography. Semin Radiat Oncol 2016;27(1):310. DOI: 10.1016/j.semradonc.2016.08.002

5. Parkin DM, et al. Fifty years of cancer incidence: $\mathrm{CI}$ I-IX. Int J Cancer 2010;127:2918-27. DOI: 10.1002/ijc.25517

6. Poveda-Matiz JL, et al. Evolución de la mortalidad por cáncer de próstata en Colombia: estudio ecológico. Urol Colomb 2014;23(1):3-10. Dirección URL: <http://www.elsevier.es/ es-revista-urologia-colombiana-398-articulo-evolucionmortalidad-por-cancer-prostata-X0120789X14284174>. 
7. Antczak A, et al. The variant allele of the rs188140481 polymorphism confers a moderate increase in the risk of prostate cancer in Polish men. Eur J Cancer Prev 2015;24(2):122-7. DOI: 10.1097/CEJ.00000000000000079

8. Antalis T, et al. Membrane-anchored serine proteases in health and disease. Prog Mol Biol Transl Sci 2011;99:1-50. DOI: 10.1016/B978-0-12-385504-6.00001-4

9. Fernández-Serra A, et al. Molecular characterization and clinical impact of TMPRSS2-ERG rearrangement on prostate cancer: comparison between FISH and RT-PCR. Biomed Res Int 2013;2013:465179. DOI: 10.1155/2013/465179

10. Wang J, et al. Expression of variant TMPRSS2/ERG fusion messenger RNAs is associated with aggressive prostate cancer. Cancer Res 2006;66(17):8347-51. DOI: 10.1158/00085472.CAN-06-1966

11. Whirl-Carrillo $\mathrm{M}$, et al. Pharmacogenomics knowledge for personalized medicine. Clin Pharmacol Ther. 2012;92(4):414-7. DOI: 10.1038/clpt.2012.96

12. Landrum $\mathrm{M}$, et al. ClinVar: Improving access to variant interpretations and supporting evidence. Nucleic Acids Res 2018;46(D1):D1062-D1067. DOI: 10.1093/nar/gkx1153

13. Sherry $S$, et al. dbSNP: The NCBI database of genetic variation. Nucleic Acids Res 2001;29(1):308-11.

14. Blee AM, et al. TMPRSS2-ERG controls luminal epithelial lineage and antiandrogen sensitivity in PTEN and TP53 -mutated prostate cancer. Clin Cancer Res 2018;24(18):45514565. DOI: 10.1158/1078-0432.CCR-18-0653
15. Knuuttila M, et al. Intratumoral androgen levels are linked to TMPRSS2-ERG fusion in prostate cancer. Endocr Relat Cancer 2018;25(9):807-19. DOI: 10.1530/ERC-18-0148

16. Fernández-Serra A, et al. Cáncer de próstata: la revolución de los genes de fusión. Actas Urol Esp 2011;35(7):420-8. Dirección URL: <http://www.elsevier.es/es-revista-actasurologicas-espanolas-292-articulo-cancer-prostata-revolucion-los-genes-S0210480611000702>.

17. Tomlins SA, et al. Role of the TMPRSS2-ERG gene fusion in prostate cancer. Neoplasia. Neoplasia 2008;10(2):17788. Dirección URL: <https://www.ncbi.nlm.nih.gov/pmc/ articles/PMC2244693/>.

18. Bismar TA, et al. PTEN genomic deletion is an early event associated with ERG gene rearrangements in prostate cancer. BJU Int 2011;107(3):477-85. DOI: 10.1111/j.1464410X.2010.09470.x

19. Hsu F-C, et al. Comparison of two methods for estimating absolute risk of prostate cancer based on single nucleotide polymorphisms and family history. Cancer Epidemiol Biomarkers Prev 2010;19(4):1083-8. DOI: 10.1158/10559965.EPI-09-1176

20. Karczewski KJ, et al. The ExAC browser: displaying reference data information from over 60000 exomes. Nucleic Acids Res 2017;45(D1):D840-5. DOI: 10.1093/nar/gkw971

21. Lek $M$, et al. Analysis of protein-coding genetic variation in 60,706 humans. Nature 2016;536(7616):285-91. DOI: $10.1038 /$ nature 19057

\section{AVISO IMPORTANTE}

La Revista Mexicana de Urología se convierte en una publicación solo digital, con todas las ventajas que los medios y dispositivos electrónicos ofrecen. Usted podrá revisar la información mediante el sitio web (www.revistamexicanadeurologia.org.mx) o descargando la app para Android o iPhone.

Para consultar el texto completo de los artículos deberá registrarse por una sola vez con su correo electrónico, crear una contraseña, indicar su nombre, apellidos y especialidad.

Esta información es indispensable para saber qué consulta y cuáles son sus intereses, y poder en el futuro inmediato satisfacer sus necesidades de información. 